Journal of Social Sciences (COES\&RJ-JSS)

ISSN (E): 2305-9249 ISSN (P): 2305-9494

Publisher: Centre of Excellence for Scientific \& Research Journalism, COES\&RJ LLC

Online Publication Date: $1^{\text {st }}$ October 2017

Online Issue: Volume 6, Number 4, October 2017

DOI : $10.25255 /$ jss.2017.6.4.744.761

\title{
The Implementation of Curriculum Management and School-Based Learning In Indonesian Elementary School
}

\author{
Mustiningsih \\ Department of Educational Administration, Faculty of Education, \\ Universitas Negeri Malang, Jl. Semarang 5 Malang, Indonesia
}

\begin{abstract}
:
Manajemen Berbasis Sekolah or School-based Management (SBM) in Indonesian elementary school is aimed at optimizing the quality of curriculum and learning management, because learning is the core activity in school. Development and improvement of SBM in Indonesian elementary school was implemented since 1999 and has been continuing until now. This study is generally aimed at describing the implementation of curriculum management and school-based learning in Indonesian elementary school. This study employs descriptive quantitative approach. The population of this study was all of the elementary schools in Indonesia which are spread into 34 provinces with three regions namely Western Indonesia Region (WIB), Central Indonesia Region (WITA) and Eastern Indonesia Region (WIT). The sample technique used in this study was purposive random sampling area. The samples of this study were 16 provinces, 32 districts/cities, and 96 elementary schools. The results show that the implementation of curriculum management and school-based learning in Indonesian elementary school is categorized as the excellent qualification. Of the 23 elements/aspects that become the scope of curriculum management and school-based learning in elementary school, all schools have excellent qualifications.
\end{abstract}

\section{Keywords:}

curriculum management and school-based learning, elementary school

\section{Citation:}

Mustiningsih (2017); The Implementation Of Curriculum Management And School-Based Learning In Indonesian Elementary School; Journal of Social Sciences (COES\&RJ-JSS), Vol.6, No.4, pp:744-761; DOI: 10.25255/jss.2017.6.4.744.761. 


\section{Introduction}

The implementation curriculum management and school-based learning as part of the implementation of School-based Management (SBM) in Indonesian Elementary School (SD) can be divided into 2 periods of time; they are before 2012 and 2012 and so on. In 2012, it can be considered as the milestone of reform in the field of SBM, it is also called as the pillar of SBM. Before 2012, there are 3 (three) pillars of SBM, starting in 2012, the pillars of SBM in Indonesia were expanded to 7 (seven).

SBM in Indonesia including in the elementary school is implemented since 1999 agreed with the Indonesian government in implementing the reform agenda in all areas including education management. This was stated by Jalal (2012) that the background of SBM is: "Law No 22, 1999 and Law No. 25, 1999 mandated decentralization of the government, and the education system has been decentralized".

The implementation of SBM in Indonesian elementary school was under the command of both central and local government. In 1999, the Department of National Education (now Ministry of Education and Culture), together with local government were assisted by several partner of financial institutions, technical institution and implementation. Some partnerts institutions arethe United Nations Children's Fund (UNICEF)the United Nations Children's Fund; the United Nations Educational, Scientific and Cultural Organization (UNESCO); the Asian Development Bank; the U.S. Agency for International Development (USAID); the Australian Agency for International Development; the Japan International Cooperation Agency; the Embassy of the Kingdom of the Netherlands, NZAID,AusAID, Plan International, Citibank, Save the Children, JICA,Kartika Soekarno Foundation, dan World Bankwhich also named asRAND Education(Vernez, Karam, and Marshall, 2012; Directorate of Elementary School Development, 2016).

RAND Education as one of the partner institutions that contributed to the implementation of SBM in Indonesia provided the report by describing various matters related to the characteristics of SBM in Indonesia. In the report mentioned that:

In 2003, the Indonesian government began to decentralize the governance of its primary and secondary education system as part of its decentralization of responsibilities to district governments (regencies) initiated to strengthen the country's democratic processes. Schools were given authority to manage their operations independently according to student needs and were asked to engage the local community to improve the quality of education. This decentralized form of school management, often called schoolbased management, required a major shift in how people think about schooling and a significant improvement in the capacity of principals, teachers, and the community to provide leadership, develop programmatic alternatives to meet local educational needs, and engage parents and the community in the governance of schools (Vernez, Karam, and Marshall, 2012).

The report can be interpreted that since 2003 the Indonesian government began implementing decentralized education in both primary and secondary schools. Local government is responsible for the implementation of education democracy process of the schools. Schools have the authority to independently manage according to the characteristics of students' needs and the demand of local communities in terms of quality target and school development. Decentralization in the field of education is referred to school-based management. In its implementation, it emphasizes the great role of school 
principals, teachers and communities, and the development of school programs depend on the needs of parents and local communities.

The implementation of SBM in elementary school programs with 3 pillars of management,namely Active Learning, Creative, Effective and Enjoyable (which is called PAKEM), and Community Participation/Peran Serta Masyarakat (PSM) in Indonesia were evaluated and monitored in 2000, 2002, 2005, and 2010. Evaluation results showed that SBM development programs have a positive impact, such as: (1) more transparent, participatory, democratic and eccountable, (2) improving education, (3) reducing drop-out rates; (4) improving the implementation of learning with PAKEM strategy; and (5) improving community participation in elementary school education (Directorate of Elementary School Development, 2015).

Based on the results of monitoring and evaluation, as well as scientific study on school management and the foundation of prevailing laws and regulations, in 2012, 3 (three) pillars of SBM in elementary school were developed into 7 (seven) pillars, namely: (1) curriculum and school-based learning, (2) school-based management of students, (3) school-based management of educators and education staff, (4) school-based management of facilities and infrastructure, (5) school-based management of finance, (6) school-based management of school relatioship and comunities and (7) school-based management of culture and environment.

The importance of implementing SBM in elementary school includes curriculum and learning management in Indonesia is based on the existence of several laws and regulations, such as in the Law Number 20, 2003 about the National Education in article 51 paragraph 1 stated that: "The management of early education, primary and secondary education are conducted based on the minimal standard services by the principles of school-based management". Based on the law, it is clear that SBM in Indonesia should be implemented as a principle in the management of educational units.

SBM in elementary schools is directed at optimizing the quality of pillar learning management, because learning is the core activity in school. In order to maintain the management of learning in schools, there are 6 (six) other school-based management pillars are also directed to support the optimization of laerning management. The six of SBM components that are expected to contribute in the optimization of learning management include student management, teacher and education staff management, facilities and infrastructure management, finance management, public relations management, and culture and environment management.

Optimizing the implementation of curriculum management and school-based learning in Indonesia has been implemented since the implementation of expanded SBM implementation in 2012 has resulted variation qualities of curriculum management and school-based learning in elementary schools. This study is aimed at finding qualifications for each school, province, and island also the time zones of Western Indonesia (WIB), Central Indonesia Time (WITA), and Eastern Indonesia (WIT).

The general purpose of this research is to find and describe the quality of the implementation curriculum management and school-based learning in Indonesian elementary school. Specifically, the research is aimed at describing: (1) the 
implementation of curriculum management and school-based learning in elementary school based on the distribution of time zone WIB, WITA and WIT, (2) the implementation of curriculum management and school-based learning in elementary school based on islands/island groups, and (3) the implementation of each element/aspect of curriculum management and school-based learning in Indonesian elementary schools, covers:(a) the activities of the implementation of curriculum and learning development, (b) those who involve in the main activities of curriculum and learning development, (c) the implementation of curriculum and learning development principles (d) the main activities of curriculum and learning development mechanism (e) learning load of the students in a week, month and year (f) content aspects of the lesson plan developed by the teacher $(\mathrm{g})$ the principles that being paid attention by the teachers in preparing the lesson plan (h) the implementation of three steps of teacher learning (i) the implementation of teacher's classroom management criteria, (j) the variations and use of students' learning resources (k) the forms of students' work that show communication skills,(l) the implementation of the students 'attitude, knowledge, and skills assessment (m) the procedures passed by the teacher in preparing the test questions (o) the processing of learning outcomes to assess the progress of learning outcomes and detect students' learning difficulties, (p) supervision learning procedure by the headmaster (q) the parties receiving supervision report of the learning process $(r)$ the follow-up procedure on the results of learning supervision, (s) the average value of students' learning completeness $(t)$ the aspects that need to be considered by the school principal in learning evaluation process $(\mathrm{u})$ the role of teachers in learning (w) documents that can be used to record reports on achievement of students' competence (x) reports of students' learning achievement at the end of each semester to their parents/guardian in the form of an education report book (y) the quality and quantity of books prove the curriculum and learning management activities.

SBM is a form of autonomous management of education in educational units, in which case the school principals and teachers are assisted by school committees in managing the educational activities [Elucidation of Article 51 Paragraph (1) of Law Number 20, 2003 on National Education System]. The essence of SBM is the provision of school autonomy in order to improve the quality of schools. The autonomy of schools can also be interpreted as giving more authority to schools that have meaning of self-initiative, selfwork, self-financing, self-management, and self-sufficiency. SBM can be defined as selfmanagement resource done by the schools, by involving all interest groups in decisionmaking, to achieve the goal of improving school quality (Directorate of Elementary School Development, 2012).

SBM is aimed at improving school self-sufficiency through the providing greater authority in managing school resources, and encouraging the participation of all interest groups in decision-making for school quality improvement. In particular, SBM is aimed at developing the components of curriculum and learning management beside of 6 (six) pillars (Directorate of Elementary School Development, 2015).

Curriculum management and school-based learning management are curriculum and learning arrangement that includes planning, organizing, implementing and evaluating curriculum and learning in the schools based on the implementation principles of the school-based management (Directorate of Elementary School Development, 2012). 
In 2012, in the transition period of old 3 (three) pillars of SBM to new 7 (seven) expanded pillars, the scope of curriculum management and school-based learning includes: (1) Education Unit Level Curriculum (KTSP), (2) the preparation of the education calendar (4) learning process, (5) learning planning, (6) learning implementation, (7) learning assessment, (8) learning supervision, (9) preparation of academic regulation, (10) the determination of learning load, (11) learning system, (12) learning load, (13) selection of PAKEM strategy, (14) basic concept, (15) teaching model/strategy, (16) what and why PAKEM, (17) ) the importance of PAKEM, (18) PAKEM principles, (19) the superiority of PAKEM, and (20) the characteristics of PAKEM.

The scope of curriculum management and school-based learning as the contents of the Guidance and Development Guideline for School-Based Management in Primary Schools in 2013 include: (1) school annual program, (2) preparation and elaboration of school calendars, (3) preparation of the Education calendar, (4) preparation/review KTSP, (5) preparation of lesson plan (RPP), (6) division of teaching and other jobs, (7) compilation of lesson schedule, (8) preparation of repair and enrichment activity schedule, (9) preparation of activity schedule, (10) preparation of guidance and counseling activity, (11) arrangement of source and learning media utilization, (12) arrangement of criteria and execution of student learning outcomes, class increase, and graduation, (13) arrangement of opening new academic year, 14) implementation of learning activities, (15) supervision of learning implementation, (16) supervision of guidance and counseling activities, and (17) closing school year and graduation.

\section{Research Methods}

This research employs quantitative approach of descriptive type. The use of this approach is to obtain an accurate picture upon the results of the implementation of curriculum management and school-based learning as part of the implementation of SBM in Indonesian elementary schools.

The population of this study is all elementary schools in Indonesia. Based on the Basic Education Data there are 148,135 (one hundred forty eight thousand and one hundred thirty five) schools spread over 34 (thirty four) provinces, in 3 (three) regions of WIB, WITA, and WIT zones. The dividion of three regions is not based on the time zones or based on the location of longitude and latitude of the earth, but determined by the researcher based on the consideration of relatively homogeneous regional conditions.

There are 16 (sixteen) provinces include in West Indonesia Regions: (1) Nangru Aceh Darussalam, (2) North Sumatra, (3) West Sumatra, (4) Riau, (5) Riau Islands (6) Jambi, (7) South Sumatra, (8) Lampung,(9) Bangka Belitung, (10) Bengkulu, (11) Special Capital Region (DKI) Jakarta, (12) West Java, (13) Banten, (14) Central Java, (15) Special Region of Yogyakarta, and (16) East Java. Central Indonesia Region, there are 8 (eight) provinces: (1) West Kalimantan, (2) East Kalimantan, (3) North Kalimantan, (4) East Kalimantan, (5) South Kalimantan, (6) Bali, (7) West Nusa Tenggara (NTB), and (8) East Nusa Tenggara (NTT). East Indonesia includes: (1) South Sulawesi, (2) Southeast Sulawesi, (3) Central Sulawesi, (4) North Sulawesi, (5) West Sulawesi, (6) Gorontalo, (7) Maluku, (8) North Maluku, (9) Papua, and (10) West Papua.

By considering that the number of population is too much, it needs to take representative sample. The sample technique used in this study was purposive random sampling area. 
The sampling area is used to divide the province into a population, it was divided into 3 (three) areas, ie WIB, WITA and WIT. Purposive sampling was applied to determine the number of provinces for each area of WIB, WITA and WIT. This technique was used for each area since it based on certain considerations that it can represent the characteristics of the homogeneity of the regions. From WIB region, 6 (six) provinces was selected, WITA was 5 (five) provinces, and WIT was 5 (five) provinces. Random sampling is used to determine samples of two districts/cities for each province and also to determine the three primary schools for each district/cities that were used as research samples.

Based on these criteria, sampling is carried out by the steps of: (1) determining the research sample of 16 provinces from 34 provinces in Indonesia, (2) determining the target of districts/cities from each province, 2 (two) regencies in maximum, so the total is 32 (thirty two) regencies/cities and (3) establishing 3 sample schools from each district/city, resulting 96 (ninety six) elementary.

Based on the sampling technique, the population and sample of this study are presented in Table 1.

Table 1 Population and Sample Research by Province and Regency/City

\begin{tabular}{|c|c|c|c|c|c|}
\hline No & $\begin{array}{l}\text { Distributi } \\
\text { on of } \\
\text { regions }\end{array}$ & Province & \multicolumn{2}{|c|}{ Regency/City } & $\begin{array}{c}\text { Number } \\
\text { of } \\
\text { Elementar } \\
\text { y Schools }\end{array}$ \\
\hline & WIB & North Sumatra & Medan City & Binjai City & 6 \\
\hline & WIB & West Sumatra & Padang City & $\begin{array}{l}\text { Payakumbuh } \\
\text { City }\end{array}$ & 6 \\
\hline & WIB & SumatraSouth & $\begin{array}{l}\text { Ogan Ilir } \\
\text { regency }\end{array}$ & City Palembang & 6 \\
\hline & WIB & WestJava & Bandung City & $\begin{array}{l}\text { Sumedang } \\
\text { Regency }\end{array}$ & 6 \\
\hline & WIB & Central Java & Semarang City & Batang Regency & 6 \\
\hline & WIB & East Java & Malang City & Blitar Regency & 6 \\
\hline & WITA & Bali & Denpasar City & Bangli Regency & 6 \\
\hline & WITA & $\begin{array}{l}\text { EastNusa } \\
\text { Tenggara }\end{array}$ & Kupang City & $\begin{array}{l}\text { Timur Tengah } \\
\text { Selatan Regency }\end{array}$ & 6 \\
\hline & WITA & $\begin{array}{l}\text { WestKalimanta } \\
\mathrm{n}\end{array}$ & Pontianak City & $\begin{array}{l}\text { Kubu Raya } \\
\text { Regency }\end{array}$ & 6 \\
\hline & WITA & $\begin{array}{l}\text { CentralKaliman } \\
\text { tan }\end{array}$ & $\begin{array}{l}\text { Palangkaraya } \\
\text { City }\end{array}$ & $\begin{array}{l}\text { Pulang Pisau } \\
\text { Regency }\end{array}$ & 6 \\
\hline & WITA & EastKalimantan & Balikpapan City & $\begin{array}{l}\text { Kutai } \\
\text { Kartanegara } \\
\text { Regency }\end{array}$ & 6 \\
\hline & WIT & NorthSulawesi & Tomohon City & Manado City & 6 \\
\hline & WIT & $\begin{array}{l}\text { CentralSulawes } \\
\text { i }\end{array}$ & Palu City & $\begin{array}{l}\text { Donggala } \\
\text { Regency }\end{array}$ & 6 \\
\hline & WIT & SouthSulawesi & Makasar City & $\begin{array}{l}\text { Jeneponto } \\
\text { Regency }\end{array}$ & 6 \\
\hline & WIT & Maluku & Ambon City & $\begin{array}{l}\text { Southeast } \\
\text { MalukuRegency }\end{array}$ & 6 \\
\hline
\end{tabular}


The Implementation Of Curriculum Management ......

\begin{tabular}{ccclc}
\hline WIT & Papua & Jayapura City & Keeron Regency & 6 \\
\hline & Total & $\mathbf{1 6}$ & $\mathbf{1 6}$ & $\mathbf{9 6}$ \\
\hline
\end{tabular}

The names of the schools as the sample after random sampling were presented in Table 2 .

Table 2. The Regency/City and the name of Schools as the sample of the study

\begin{tabular}{|c|c|c|c|}
\hline No & Province & Regency/City & School \\
\hline & NorthSumatra & Medan City & SD Percobaan \\
\hline & NorthSumatra & Medan City & SDN No. 064979 \\
\hline & NorthSumatra & Medan City & SD Swasta Model Al Azhar \\
\hline & NorthSumatra & Binjai Regency & SDN NO. 024772 Binjai \\
\hline & NorthSumatra & Binjai Regency & SDN NO. 020259 Binjai \\
\hline & NorthSumatra & Binjai Regency & SDN NO. 020267 Binjai \\
\hline & Riau & Pekanbaru City & SDN 65 Pekanbaru \\
\hline & Riau & Pekanbaru City & SDN 11 Pekanbaru \\
\hline & Riau & Pekanbaru City & SDN 83 Pekanbaru \\
\hline & Riau & Pelelawan Regency & SDN 006 Pangkalan Kerinci \\
\hline & Riau & Pelelawan Regency & SDN 007 Pangkalan Kerinci \\
\hline & Riau & Pelelawan Regency & SDN 004 Bukit Agung \\
\hline & South Sumatra & Ogan Ilir Regency & SDN II Tanjung Pura \\
\hline & South Sumatra & Ogan Ilir Regency & SDN II Indralaya \\
\hline & South Sumatra & Ogan Ilir Regency & SDN 05 Indralaya \\
\hline & South Sumatra & Palembang City & SDN 165 Palembang \\
\hline & South Sumatra & Palembang City & SDN 230 Palembang \\
\hline & SouthSumatra & Palembang City & SDN 140 Palembang \\
\hline & WestJava & Sumedang Regency & SDN Pasanggrahan I \\
\hline & WestJava & Sumedang Regency & SDN Tegalkalong I \\
\hline & WestJava & Sumedang Regency & SDN Gudang I \\
\hline & WestJava & Bandung City & SDN Sejahtera 4 \\
\hline & WestJava & Bandung City & SDN Andir Kidul \\
\hline & WestJava & Bandung City & SDN Asmi \\
\hline & Central Java & Batang Regency & SDN Wonokerso 01 \\
\hline & Central Java & Batang Regency & SDN Tegalsari 02 \\
\hline & Central Java & Batang Regency & SDN Sawahjoho 01 \\
\hline & Central Java & Semarang City & $\begin{array}{l}\text { SDN Pedurungan Central02 } \\
\text { Semarang }\end{array}$ \\
\hline & Central Java & Semarang City & SDN Kepunden \\
\hline & Central Java & Semarang City & SD Hj. Isriati Baiturrahman \\
\hline & East Java & Malang City & SDN Purwantoro I Malang \\
\hline & East Java & Malang City & SD Insan Amanah Malang \\
\hline & East Java & Malang City & SDN Pandan Wangi 1 Malang \\
\hline & East Java & Blitar Regency & SDN Kanigoro 03 \\
\hline & East Java & Blitar Regency & SDN Kademangan 01 \\
\hline & East Java & Blitar Regency & SDN Kademangan 05 \\
\hline & Bali & Denpasar Regency & SDPN Tulangampiang \\
\hline & Bali & $\begin{array}{c}\text { Denpasar Regency } \\
750\end{array}$ & SDN 8 Dauh Puri \\
\hline
\end{tabular}




\begin{tabular}{|c|c|c|c|}
\hline No & Province & Regency/City & School \\
\hline & Bali & Denpasar Regency & SDN 1 Sumerta \\
\hline & Bali & Bangli Regency & SDN 2 Kawan \\
\hline & Bali & Bangli Regency & SDN 1 Cempaga \\
\hline & Bali & Bangli Regency & SDN 1 Nemulih \\
\hline & EastNusa Tenggara & Kupang City & SD Inpres Oesapa Kecil 1 \\
\hline & East Nusa Tenggara & Kupang City & SDK Don Bosko 2 \\
\hline & East Nusa Tenggara & Kupang City & SDN Bertingkat Naikoten \\
\hline & EastNusa Tenggara & TtsRegency & SD Inpres Sekip \\
\hline & East Nusa Tenggara & TtsRegency & SD GMIT Soe I \\
\hline & East Nusa Tenggara & TtsRegency & SD Inpres Oenali \\
\hline & WestKalimantan & Pontianak City & SDN 34 Pontianak \\
\hline & West Kalimantan & Pontianak City & SDN 03 Pontianak \\
\hline & West Kalimantan & Pontianak City & SDN 19 Pontianak \\
\hline & WestKalimantan & Kubu Raya Regency & SDN 03 Sungai Raya \\
\hline & West Kalimantan & Kubu Raya Regency & SDN 9 Sungai Raya \\
\hline & West Kalimantan & Kubu Raya Regency & SDN 10 Sungai Kakap \\
\hline & & Pulang Pisau & \\
\hline & CentralKalimantan & Regency & SDN Pulang Pisau 2 \\
\hline & & Pulang Pisau & \\
\hline & CentraKalimantan 1 & Regency & SDN Pulang Pisau 5 \\
\hline & & Pulang Pisau & \\
\hline & Central Kalimantan & Regency & SDN Pulang Pisau 7 \\
\hline & CentralKalimantan & Palangka Raya City & SDN Percobaan Palangka Raya \\
\hline & Central Kalimantan & Palangka Raya City & SDN 8 Langkai \\
\hline & Central Kalimantan & Palangka Raya City & SDN 1 Tumbang Tahai \\
\hline & EastKalimantan & Balikpapan City & SD Kemala Bhayangkari \\
\hline & East Kalimantan & Balikpapan City & SDN 03 BPP City \\
\hline & East Kalimantan & Balikpapan City & SDN 001 Balikpapan City \\
\hline & East Kalimantan & $\begin{array}{l}\text { Kutai Kartanegara } \\
\text { Regency }\end{array}$ & SDN 018 Tenggarong \\
\hline & East Kalimantan & $\begin{array}{l}\text { Kutai Kartanegara } \\
\text { Regency }\end{array}$ & SDN 028 Tenggarong \\
\hline & EastKalimantan & $\begin{array}{l}\text { Kutai Kartanegara } \\
\text { Regency }\end{array}$ & SDN 002 Tenggarong \\
\hline & NorthSulawesi & Tomohon City & SD GMIM IV Tomohon \\
\hline & North Sulawesi & Tomohon City & SD Katholik I Tomohon \\
\hline & North Sulawesi & Tomohon City & SD Inpres Kumelembum \\
\hline & North Sulawesi & Manado City & SDN 06 Manado \\
\hline & North Sulawesi & Manado City & SDN 11 Manado \\
\hline & North Sulawesi & Manado City & SDN 12 Manado \\
\hline & CentralSulawesi & Palu City & SDN 15 Palu \\
\hline & Central Sulawesi & Palu City & SDN 3 Palu \\
\hline & Central Sulawesi & Palu City & SDN Model Terpadu Madani \\
\hline & Central Sulawesi & DonggalaRegency & SDN I Loli Tasibuni \\
\hline & Central Sulawesi & DonggalaRegency & SDN Lomboto \\
\hline & Central Sulawesi & DonggalaRegency & SDN NO. 1 Boya Donggala \\
\hline & SouthSulawesi & $\begin{array}{r}\text { Makassar City } \\
751\end{array}$ & SDN Inpres Bertingkat Labuan \\
\hline
\end{tabular}


The Implementation Of Curriculum Management ......

\begin{tabular}{|c|c|c|c|}
\hline No & Province & Regency/City & School \\
\hline & & & Baji \\
\hline & South Sulawesi & Makassar City & SD Inpres Tellp Baru 3/1 \\
\hline & South Sulawesi & Makassar City & SD Filadelfia \\
\hline & South Sulawesi & Jeneponto Regency & SDI No. 13 Unggulan Balang Ii \\
\hline & South Sulawesi & Jeneponto Regency & SDI No. 125 Allu \\
\hline & South Sulawesi & Jeneponto Regency & SDN No. 64 Tanatoa \\
\hline & Maluku & $\begin{array}{l}\text { Maluku Tenggara } \\
\text { Barat Regency }\end{array}$ & SD Naskat Don Bosco Ii \\
\hline & Maluku & $\begin{array}{l}\text { Maluku Tenggara } \\
\text { Barat Regency }\end{array}$ & SDN I Saumlaki \\
\hline & Maluku & $\begin{array}{l}\text { Maluku Tenggara } \\
\text { Barat Regency }\end{array}$ & SD Kristen Saumlaki \\
\hline & Maluku & Ambon City & SDN 3 Halong \\
\hline & Maluku & Ambon City & SDN Seilate \\
\hline & Maluku & Ambon City & SD Inpres 19 Ambon \\
\hline & Papua & Keerom Regency & SDN Inpres I Arso \\
\hline & Papua & Keerom Regency & SDN Inpres Pir Iv Arso \\
\hline & Papua & Keerom Regency & SD Inpres I Arso 2 \\
\hline & Papua & Jayapura City & SD YPPK Gembala Baik \\
\hline & Papua & Jayapura City & SDN Cityraja \\
\hline & Papua & Jayapura City & SDN Inpres Perumas I Waena \\
\hline
\end{tabular}

The instrument of this study is closed questionnaire. The technique of data collection is by going directly to school which become sample of this study, that is 16 province, 32 regencies/cities and 96 schools. In the implementation of data collection, besides using questionnaires, this study also used interviews and documentation.

Preparation of items in this instrument was based on the purpose of the study, that is divided into 14 indicators. The following indicators are: (1) the activities of curriculum and learning development, (2) the parties involved in curriculum and learning development, (3) curriculum development and learning principles, (4) curriculum and learning arrangement mechanism, (5) learning load (6) lesson plan (RPP), (7) instructional implementation, (8) teacher management criteria, (9) students 'learning resources, (10) students' works that show communication skills, (10) ) learning assessment, (11) learning supervision, (12) the role of teachers in learning, (13) documentation activities in the form of books, and (14) scoring criteria using these provisions: (a) rate A has 4 score, (b) rate B has 3 score, (c) rate $\mathrm{C}$ has 2 score, and (d) rate D has 1 score. The collected data is analyzed by descriptive analysis techniques to find percentage and average. The scoring results are interpreted based on existing guidelines for subsequent discussion. Interpretation guidelines are presented in Table 3 to determine the school success qualification in the implementation of curriculum management and school-based learning, reviewed from the school level, regency/city, province, islands/ island groups, time zones and national.

Table3 Data Interpretation Guidelines

No Score Range Qualification




\begin{tabular}{ccc}
1 & $86-100$ & Very Good \\
\hline 2 & $71-85$ & Good \\
\hline 3 & $56-70$ & Adequate \\
\hline 4 & $36-55$ & Less \\
\hline 5 & $1-35$ & Very Less \\
\hline
\end{tabular}

\section{Research Result}

The Implementation of Curriculum Management and School-based Learning in National Elementary School

The implementation of curriculum management and school-based learning in Indonesian Elementary School is in the excellent qualification with an average score of 92 . Three provinces showed the highest score upon the implementation of curriculum management and school-based learning, namely Java East shows 99 of representative score, while Sumatra North and Kalimantan East show 97 of representative score. All of the three provinces are included in the excellent qualification. The three provinces with the lowest scores were Central Sulawesi, Bali and Central Kalimantan with representative score of 87,86 and 75. From three provinces with the lowest scores, only the Central Kalimantan got good score. Even the other 15 provinces got scores that categorized into very good categories. The result of overall scores for each province from the highest to the lowest is presented orderly in Table 4.

Table 4 Rankand Qualification of the Implementation of Curriculum Management and School-based Laerning in Indonesian Elementary Schools

\begin{tabular}{llccl}
\hline No & Province & Score & Rank & Qualification \\
\hline & East Java & 99 & 1 & Very Good \\
\hline North Sumatra & 97 & 2.5 & Very Good \\
\hline East Kalimantan & 97 & 2.5 & Very Good \\
\hline Riau & 95 & 5 & Very Good \\
\hline Central Java & 95 & 5 & Very Good \\
\hline North Sulawesi & 95 & 5 & Very Good \\
\hline West Java & 94 & 7.5 & Very Good \\
\hline West Kalimantan & 94 & 7.5 & Very Good \\
\hline Maluku & 92 & 9.5 & Very Good \\
\hline Papua & 92 & 9.5 & Very Good \\
\hline South Sumatra & 88 & 12 & Very Good \\
\hline East Nusa Tenggara & 88 & 12 & Very Good \\
\hline South Sulawesi & 88 & 12 & Very Good \\
\hline Central Sulawesi & 87 & 14 & Very Good \\
\hline Bali & 86 & 15 & Very Good \\
\hline Central Kalimantan & 75 & 16 & Good \\
\hline & Average & 92 & - & Sangat baik \\
\hline
\end{tabular}

The Implementation of Curriculum Management and School-based Learning in Indonesian Elementary School based on Time Zones Division of WIB, WITA and WIT 
Reviewed from the division of Indonesian time zones ie WIB, WITA and WIT, the implementation of curriculum management and school-based learning in elementary school can be concluded that WIB has the highest score (95) means very good, followed by WIT with score 91, it is categorized as very well, and the last is WITA with score 88 , it is also very good qualification. The following results are presented based on the time zones division.

Table 5 Rankand qualification of the Implementation of Curriculum Management and School-based Learning in Indonesian elementary Schools based on Time Zones Division

\begin{tabular}{clccc}
\hline No & Time Zones Division & Score & Rank & Qualification \\
\hline & WIB & 95 & 1 & Very Good \\
\hline WIT & 91 & 2 & Very Good \\
\hline WITA & 88 & 3 & Very Good \\
\hline
\end{tabular}

The Implementation of Curriculum Management and School-based Laerning in Indonesian Elementary Schools based on the Islands/Island groups

Reviewed from the division of islands/island groups, the implementation of curriculum management and school-based learning in Indonesian elementary schools found that Java has the highest score of 96 with very good qualifications, and the lowest is Bali with a score of 86 , and the qualification is also very good. Complete results are elaborated in the Table 6.

Table 6 Rank of the Implementation of Curriculum Management and School-based Learning in Indonesian Elementary schools based on the division of Islands/Island groups

\begin{tabular}{|c|c|c|c|c|}
\hline No & Province & Score & Rank & Qualification \\
\hline & Java & 96 & 1 & Very Good \\
\hline & Sumatra & 93 & 2 & Very Good \\
\hline & Maluku & 92 & 3.5 & Very Good \\
\hline & Papua & 92 & 3.5 & Very Good \\
\hline & Sulawesi & 90 & 5 & Very Good \\
\hline & Kalimantan & 88 & 6.5 & Very Good \\
\hline & East Nusa Tenggara & 88 & 6.5 & Very Good \\
\hline & Bali & 86 & 8 & Very Good \\
\hline
\end{tabular}

Implementation of each Element/Aspect of Curriculum Management and SchoolBased Learning in Indonesian Elementary Schools

The implementation of curriculum management and school-based learning in Indonesian elementary schools based on elements/aspect of curriculum management and school-based learning can be concluded that the highest qualification aspect is the content of Lesson Plan/RPP made by teachers with score of 98.2, then next are the aspects of curriculum development and learning activities with score of 97.4 which are included in very good qualifications. The lowest qualification is the aspect of the learner's work that show communication skills with very good score of 82.6. One level above is the main activity aspect of curriculum and learning mechanism, with score of 83.1 included in very good category. In order scores for each element/aspect of curriculum management and schoolbased learning from highest to lowest are elaborated in Table 7. 
Table 7. Rank and Qualification of the elements/aspects of the Implementation of Curriculum Management and School-based Learning in Indonesian Elementary schools

\begin{tabular}{|c|c|c|c|c|}
\hline No & $\begin{array}{l}\text { Elements/aspects of the } \\
\text { Implementation of Curriculum } \\
\text { Management and School-based } \\
\text { Learning }\end{array}$ & Score & Rank & Qualification \\
\hline & $\begin{array}{l}\text { Content aspects of the lesson plan } \\
\text { developed by the teacher }\end{array}$ & 98.2 & 1 & Very Good \\
\hline & $\begin{array}{l}\text { The activities of the implementation of } \\
\text { curriculum and learning development }\end{array}$ & 97.4 & 2 & Very Good \\
\hline & $\begin{array}{l}\text { The aspects that need to be considered by } \\
\text { the school principal in learning } \\
\text { evaluation process }\end{array}$ & 96.6 & 3 & Very Good \\
\hline & $\begin{array}{l}\text { Documents that can be used to record } \\
\text { reports on achievement of students' } \\
\text { competence }\end{array}$ & 96.4 & 4 & Very Good \\
\hline & $\begin{array}{l}\text { The processing of learning outcomes to } \\
\text { assess the progress of learning outcomes } \\
\text { and detect students' learning difficulties }\end{array}$ & 95.8 & 5 & Very Good \\
\hline & $\begin{array}{l}\text { Learning load of the students in a week, } \\
\text { month and year }\end{array}$ & 95.3 & 6 & Very Good \\
\hline & The role of teachers in learning & 94.8 & 7 & Very Good \\
\hline & $\begin{array}{l}\text { The quality and quantity of books prove } \\
\text { the curriculum and learning management } \\
\text { activities }\end{array}$ & 94 & 8 & Very Good \\
\hline & $\begin{array}{l}\text { Those who involve in the main activities } \\
\text { of curriculum and learning development }\end{array}$ & 93.5 & 9.5 & Very Good \\
\hline & $\begin{array}{l}\text { Supervision learning procedure by the } \\
\text { headmaster }\end{array}$ & 93.5 & 9.5 & Very Good \\
\hline & $\begin{array}{l}\text { The procedures passed by the teacher in } \\
\text { preparing the test questions }\end{array}$ & 93.2 & 11 & Very Good \\
\hline & $\begin{array}{l}\text { The implementation of curriculum and } \\
\text { learning development principles }\end{array}$ & 92.7 & 12.5 & Very Good \\
\hline & $\begin{array}{l}\text { The principles that being paid attention } \\
\text { by the teachers in preparing the lesson } \\
\text { plan }\end{array}$ & 92.7 & 12.5 & Very Good \\
\hline & $\begin{array}{l}\text { Reports of students' learning achievement } \\
\text { at the end of each semester to their } \\
\text { parents/guardian in the form of an } \\
\text { education report book }\end{array}$ & 91.4 & 14 & Very Good \\
\hline & $\begin{array}{l}\text { The implementation of three steps of } \\
\text { teacher learning }\end{array}$ & 90.1 & 15 & Very Good \\
\hline & $\begin{array}{l}\text { The parties receiving supervision report } \\
\text { of the learning process }\end{array}$ & 89.8 & 16 & Very Good \\
\hline & $\begin{array}{l}\text { The variations and use of students' } \\
\text { learning resources }\end{array}$ & 88.5 & 17 & Very Good \\
\hline & $\begin{array}{c}\text { The criteria implementation of teacher's } \\
755\end{array}$ & 87 & 18 & Very Good \\
\hline
\end{tabular}


The Implementation Of Curriculum Management ......

\begin{tabular}{lllll}
\hline classroom management & & & \\
\hline $\begin{array}{l}\text { The average value of students' learning } \\
\text { completeness }\end{array}$ & 85.4 & 19 & Very Good \\
$\begin{array}{l}\text { The implementation of the students' } \\
\text { attitude, knowledge, and skills } \\
\text { assessment using various techniques }\end{array}$ & 85.2 & 20 & Very Good \\
$\begin{array}{l}\text { The follow-up procedure on the results of } \\
\text { learning supervision }\end{array}$ & 84.9 & 21 & Very Good \\
$\begin{array}{l}\text { The main activities of curriculum and } \\
\text { learning development mechanism }\end{array}$ & 83.1 & 22 & Very Good \\
$\begin{array}{l}\text { The forms of students' work that show } \\
\text { communication skills }\end{array}$ & 82.6 & 23 & Very Good \\
\hline
\end{tabular}

Discussions

The Implementation of Curriculum Management and School-based Learning in National Elementary Schools

The implementation of curriculum management and school-based learning in Indonesian elementary schools is included very good qualification. This may be influenced by many treatments or guidance and development carried out by the government and partner institutions. Since 1999 the SBM program has been implemented by the government and several partner institutions. From a variety of long enough guidance and development, it is now possible to achieve very good qualification for SBM implementation in Indonesian elementary schools. Word Bank Report, made in 2003 stated that:

The results of the study suggest that although schools perceived that they had autonomy to make independent decisions; .... The study also found that the transparency of information and accountability by the districts, parents and the local community were minimal. Factors such as principal and teacher leadership and preparedness were associated with levels of autonomy and accountability. There were also regional differences in implementation. The impact of school autonomy and accountability on achievement was weak due to levels of implementation.

Since 2000, SBM in Indonesia has been getting improvement from various parties. The results are pretty good since it implemented in 1999 and evaluated through Word reports in 2003. The reports showed school autonomy in making decisions; the existence of transparency and accountability of information for parents, community and Education Office/Government. Leadership factors affect school autonomy and accountability; each region has a difference in the implementation of SBM program. As a result, the implementation in terms of autonomy and accountability has different qualities.

In the other occasions, World Bank in 2007 reported also that it has been more than two decades, many countries including Indonesia have been implementing SBM well. Through accountability implementation, changes towards decentralization of schools prove or impact on the development/improvement of students and teachers performance. The report is elaborated as follows.

Over the past two decades, many countries have been implementing accountability-based, school decentralization reforms such as School-Based Management (SBM) as a way to improve student and school performance. Today, more than 800 SBM programs have been implemented in two dozen countries ranging from Australia, the 
United States, Spain, Mexico, Cambodia, Mozambique, and most notably for this paper, Indonesia (World Bank, 2007).

Barrera, et.al. (2009) mentioned that in Indonesia, since the reform of designing education by prioritizing school autonomy and increasing community participation for the benefit of learning was called school-based management (SBM), it stated as follows: "Indonesia's SBM design incorporates some features that are considered as essential to effective SBM (Barrera- Osorio et al., 2009). First, the Indonesian reform is designed to provide a high level of autonomy to schools and encourage broad participation of the local community in school affairs".

Unicef in 2015 conducted an evaluation of SBM guidance that expanded to 7 pillars as a result of the guidance conducted jointly by the government. The results of the seven pillars of SBM have different qualities in each region, but in general, the implementation of SBM is reported to have very good qualifications (UNICEF, 2015).

The implementation of SBM in Indonesia has very good qualifications, but it possibly also influenced by the elements of SBM activity, since the activity is basically the daily management work in school. The seven expanded pillars are basically in accordance with juridical, empirical and scientific studies, so that the implementation is not difficult. An effective school or an excellent school is automatically has a good SBM.

In this study, the sample is generally the schools that were given special guidance both the government and even through partner institutions to implement SBM, both the old 3 pillars and new 7 pillars. Therefore the overall quality of SBM school samples is very good qualified in average.

The implementation of SBM in elementary school in terms of provinces can be concluded that East Java has the highest score of 99. This almost perfect value is likely because of many pilot projects from various partner institutions such as UNESCO, UNICEF and USAID using East Java as one of the sample provinces. In addition, the development of SBM in elementary school is done by the government, in this case the Directorate of Elementary Education, and the Provincial Education Office, as well as some of the Regency/City Education Offices in East Java which are mostly paying attention to the continuity of SBM programs that must be implemented consistently in schools throughout East Java. Even other related programs to the quality improvement are also considered by the Provincial Education Office.

For the lowest implementation of SBM in elementary schools is Central Kalimantan, it may be due to the lack of continuity of the programs and the lack of consistent guidance to implement SBM as a mandate of the law. Practitioners in the field, such as school principals, teachers and even parents, often ignore programs that have been initiated and nurtured intensively by both government and partner institutions. They are often no longer active in doing SBM programs when pilot projects are finished or gudance from the government is stagnant. 
The Implementation of each element/aspect of Curriculum Management and Schoolbased Learning in Indonesian Elementary Schools

Seen from 23 elements or aspects in the field of curriculum management and school-based learning, and based on the results of the study show that the aspect with the highest score is the load of lesson plan/RPP developed by the teacher. The results of this study are in accordance with the World Bank report in 2003 regarding the implementation of SBM in Indonesia, mentioned that: "Teacher influence: the level of influence teachers have over instruction, development of syllabi, instructional methods, grouping of students, and use of achievement tests". This implies that in the implementation of SBM, the influence of teachers related to learning, syllabus development, learning methods, student grouping, and the use of development tests is imoortant. Thus, the preparation of the lesson plan is one of the most important things in teacher autonomy.

In the implementation of SBM, teachers have autonomy to develop learning independently. This is the effect of school self-sufficiency in making decisions. Teachers along with parents and other stakeholders in the SBM program have proven improving the quality of school and student learning. This was stated by DeGrauwe (2005):

In SBM, the focus on the increased autonomy of schools is paired with increased accountability. Giving schools, principals and teachers greater autonomy means that their actions should be answerable to parents, the community, as well as central governments. Such oversight by various stakeholders is argued to improve school quality and student learning (De Grauwe, 2005).

This point of view also reinforced the opinion of Nakaya cited in Shoraku (2008) which stated that: "Importantly, pupils or students, parents and other community members as well as teachers need to participate in the formulation and implementation of the plans and programmes. In SBM, the most important thing is participation of the students, parents and the community in supporting the needs of teachers in planning and implementing learning programs. This can be interpreted that the good preparation of teachers' lesson plan/RPP can not be separated from the good role of parents and the community for the importance of improving the quality of learning in schools.

Barrera, et.al. (2009) said that: "School principals and teachers are provided with increased autonomy to make decisions across key school areas related to school operations, budget, and education".School principals and teachers always increase autonomy in making decisions related to operations, financing and education including learning. Therefore the teachers have the autonomy in preparing the lesson plan/RPP independently whose components must be in agreee with applicable laws and regulations. It is not difficult for teachers to prepare the lesson plan which components have been set in legislation, as they also receive guidance from the school principals, school supervisors, heads of education offices and keynote speakers who specialize in lesson plan/RPP through various trainings.

Preparation of a good lesson plan/RPP is also influenced by the role of the Teachers Working Group (KKG). In this forum, teachers have the opportunity to learn and gain experience about information and skills related to learning. In this forum there are also learning monitoring activities conducted by each school. In the Word Bank report (2003) stated that: 
Teacher influence on instructional matters was positively associated with the adequacy of $K K G$ support. The latter gives teachers opportunities to share information and experiences and provides them with instructional skills. Such skills are necessary for them to exercise control over instructionally related matters at their schools.

The lowest element/aspect of curriculum management and school-based learning is the work of students that demonstrate communication skills. This is posibly influenced by policy factors about the National Examination (UN). The results of student learning in Indonesia are generally often measured only from the results of the UN. Teachers through the school principal are often urged by the Head of Department to always improve the value of UN every year. It might be the lack of teachers in developing technical exam or student learning evaluations that are not directly related to UN, including the lack of teacher training on students' communication skills. This phenomenon is also raised by various researches in Indonesia, as reported by the Ministry of Education and Culture in the document ofMinistry of Education and Culture (MoEC, 2013):

National test results Indonesia's education system assesses students with a National Examination (Ujian Nasional - UN) administered by the MoEC. This currently covers maths, natural sciences and Indonesian language. The exam is conducted at the end of classes 6, 9, and 12 as a prerequisite to move to a higher grade. While over time the exam results show some improvement in education performance, serious concerns have been raised about the validity and reliability of the tests in measuring student learning, particularly given issues with the administration of the tests and the security of exam papers (MoEC 2013).

The test system in Indonesia employs National Examination (UN) under coordination by the Ministry of Education and Culture (MoEC) includes subjects of math, science and Bahasa Indonesia. The exams are held for 6th, 9th and 12th grade students. The exam results are used for admission consideration at the next educational institution level. The results of exam are considered as a measure of educational performance quality development in schools, so the test is prepared by measuring the validity and reliability that is possible to measure students learning. Various parties are involved for securing national exam papers.

Furthermore, Tobias (2014) argued about the weakness of national examination which he called as too radical or authoritarian. He stated that: "The national media has frequently highlighted accusations of institutionalised cheating at the school level and several commentators have called for the exam system to be radically overhauled".

Whatever the reason, the national examination/UN is still maintained until now even though UN is not used as a major consideration for students' graduation. However, the results of UN are still used for a consideration of entry selection in the next educational level, including elementary school graduates who will go to junior high school. UN as one of the frightening specter for the school principal and teachers since it should be prepared throughout the year. This allows teachers to forget the variety of test techniques to accommodate students with different characteristics. It is also possible that teachers forget to prepare students' works and also forget to prepare students' works which associated with communication skills.

\section{Conclusions}


Based on the research results, it can be concluded as follows. The implementation of curriculum management and school-based learning in Indonesian elementary schools is categorized in very good qualification. From the 16 provinces, only one province, that is Central Kalimantan has good qualifications in the implementation of SBM. The rest of them, that is 15 provinces have very good qualification. The implementation of curriculum management and school-based learning in elementary school based on the division of regions; west, central, and east divisions, it can be concluded that the implementation of SBM in west Indonesia found the best result, followed by east Indonesia, and the last was central Indonesia.

The implementation of curriculum management and school-based learning in Indonesian elementary school based on islands/island groups respectively from highest to lowest is Java, Sumatra, Maluku, Papua, Sulawesi, Kalimantan, East Nusa Tenggara and Bali. The implementation of curriculum management and school-based learning in Indonesian elementary school reviewed based on the elements/aspects of curriculum management and school-based learning can be concluded that the highest qualification aspect is the content of leasson plan created by teachers. The lowest qualification is the students' works that demonstrate communication skills. From the 23 elements/aspects that become the scope of curriculum management and school-based learning in elementary school, all of them have very good qualifications.

Based on the results of the study, it suggests for the government, both at the central level through the Directorate of Elementary School Development of Kemdikbud and the Provincial Government in the Regency/City should conduct continuous development and improvement, so that the quality of implementation of curriculum management and school-based learning in elementary school can be maintained well. In addition, the government should also monitor and evaluate continuously and programmatically related to the implementation of curriculum management and school-based learning in elementary school.

The school supervisors should increase the program of development and improvement of the implementation of curriculum management and school-based learning in elementary school, so that the quality of its excellent implementation can be maintained. This can be done through continue the program of teachers working group/KKG or other relevant techniques. School supervisors should also use this sample schools as apprenticeship for other schools which implementation of curriculum management and school-based learning is not good yet.

The school principals who are the subject of this study are advised to maintain the implementation of SBM in their schools, and to reinforce the best practice that has been done in their school to other schools. As for other school principals should learn from the best practice of these sample schools in order to implement better curriculum management and school-based learning.

For the teachers in sample schools should maintain good practice in curriculum management and school-based learning, by developing the teachers working group/KKG or other means. Teachers at other schools can learn from teachers in these sample schools. 
In order to maintain and improve the implementation of curriculum management and school-based learning, parents and students should continue to provide supports in schools. The supports can be both material and non-material ie suggestions, point of view and opinions to improve the quality of schools in general, and for the implementation of curriculum management and school-based learning in particular

\section{References}

De Grauwe, A. 2005. Improving the Quality of Education Through School-Based Management: Learning From International Experiences. Review of Education 51, 269287.

Direktorat Pembinaan SD Kemdikbud. 2012. Panduan Pembinaan Manajemen Berbasis Sekolah (MBS) di Sekolah Dasar (Buku I). Jakarta: Direkorat Pembinaan SD Direktorat Pendidikan Dasar Kemdikbud.

Direktorat Pembinaan SD Kemdikbud. 2013. Pola Pembinaan dan Pengembangan Manajemen Berbasis Sekolah di Sekolah Dasar. Jakarta: Direkorat Pembinaan SD Direktorat Pendidikan Dasar Kemdikbud.

Direktorat Pembinaan SD Kemdikbud. 2015. Panduan Pelaksanaan Manajemen Berbasis Sekolah di Sekolah Dasar. Jakarta: Direkorat Pembinaan SD Direktorat Pendidikan Dasar Kemdikbud.

Direktorat Pembinaan Sekolah Dasar. 2015. Panduan Pelaksanaan Manajemen Berbasis Sekolah di Sekolah Dasar. Jakarta: Direktorat Pembinaan Sekolah Dasar Direktorat Jendral Pendidikan Dasar dan Menengah Kementerian Pendidikan dan Kebudayaan

Direktorat Pembinaan Sekolah Dasar. 2016. Panduan Pelaksanaan Manajemen Berbasis Sekolah di Sekolah Dasar. Jakarta: Direktorat Pembinaan Sekolah Dasar Direktorat Jendral Pendidikan Dasar dan Menengah Kementerian Pendidikan dan Kebudayaan Jalal, F. 2012. School Based Management (SBM): Indonesia Experiences. Palembang: UNAND.

Karam, R., Vernez, G., and Masshall, J. 2012. Examination Of School-Based Management In Indonesia. Santa Monica, CA: RAND Corporation.

Ministry of Education and Culture [MoEC] (2013). Overview of the Education Sector in Indonesia 2012: Achievements and Challenges. Jakarta: MoEC.

Sekretariat Negara RI. 2003. Undang-Undang Nomor 20 Tahun 2003 Tentang Sistem Pendidikan Nasional. Jakarta: Sekretariat Negara RI.

Shoraku, A. 2008. Educational Movement toward School-based Management in East Asia: Cambodia, Indonesia and Thailand: Background paper prepared for the Education for All Global Monitoring Report 2009. Japan: Kagawa University.

Tobias, J.; Wales, J.; Syamsulhakim, E, and Suharti. 2014. Case Study Report: Education (Towards Better Education Quality Indonesia's Promising Path). London: Overseas Development Institute.

UNICEF. 2015. Laporan Monitoring dan Evaluasi Manajemen Berbasis Sekolah di Sekolah Dasar Indonesia. Jakarta: UNICEF.

Vernez, G.; Karam, R., and Marshall, J.H. 2012. Implementation of School-Based Management in Indonesia. Santa Monica, CA: RAND Corporation.

World Bank. 2007. What is School-Based Management? Washington, D.C. 